\title{
Research on the Optimization of Campus Culture Construction in Higher Vocational Colleges
}

\section{Weiyan Li}

Shanghai Civil Aviation College, Shanghai, 200232, China

\begin{abstract}
Campus culture contains two meanings: hardware culture and software culture. Good hardware culture can give people a beautiful edification, show the distinctive industry characteristics of higher vocational colleges, make the students in them clarify their professional missions, actively study and live and subtly build the campus environment and atmosphere. Software culture is the most important aspect of a school's spiritual outlook and atmosphere. Compared with hardware culture, it is more difficult and longer to construct and innovate. The paper expounds the significance of the construction of campus culture in higher vocational colleges and the main problems, and extracts relevant countermeasures for optimizing the construction of campus culture in the colleges for the reference of relevant educators.
\end{abstract}

\section{Keywords}

higher vocational colleges; campus culture; environment; activities

\section{高职院校校园文化建设的优化研究}

\author{
李维燕
}

上海民航职业技术学院，中国・上海 徐汇 200232

\section{摘 要}

校园文化包含着两层意思：硬件文化和软件文化。好的硬件能给人以美的陶冶，展现出高职院校旗帜鲜明的行业特色，使置 身于其中的学生明确职业使命, 积极学习生活, 潜移默化的构建出校园的环境与氛围。软件文化则是体现一个学校精神面貌 与校风学风的重中之重, 较之硬件文化在建设和创新上难度更高、历时更久。论文通过阐述高职校园文化建设的意义和存在 的主要问题，提炼出优化高职校园文化建设的相关对策，以供相关教育工作者参考。

\section{关键词}

高职院校; 校园文化; 环境; 活动

\section{1 引言}

众所周知, 高职学生通常被看作是末等大学生, 他们身 上普遍具有学习态度不端正、自我管理能力差的通病。因此, 要在两年内把学生培养成为符合行业标准的人才, 学校既要 使学生掌握专业技能, 又要通过校园文化的建设将职业素养 和道德准则不断植入到学生心中, 潜移默化的强化、提升学 生的综合素质。其次, 如今课余时间占学生生活比重已接近 一半, 若校园文化缺位, 将直接导致学生课余时间使用不当, 产生不当休闲甚至违纪违法行为, 因此, 研究高职院校校园 文化建设具有重要意义。

\section{2 国际上研究现状}

中国的高职教育发展起步晚，直到 20 世纪 80 年代后期
才进入快速发展时期, 且相当数量的高职院校是从中专升格 而成的, 在办学特色上, 带着过往管理方式的痕迹。中国知 网搜索主题为 “高职校园文化” 的文章大致共 4226 篇, 这些 研究成果对于丰富校园文化建设理论, 指导校园文化建设实 践起到了积极作用。例如杨泉良、赵宗尹等人的《高职院校 校园文化建设概论》一文, 论述了校园文化建设在学校工作 中的重要地位, 强调了校园文化对实现学校教育理念的作用, 分析了高职校园文化建设的现状并提出了具体措施 ${ }^{[1]}$ 。

国际上因职业教育发展水平较高, 在职业院校的校园文 化研究方面亦成果颇丰。目前, 国际上大多数学者认为, 校 园文化是学校的历史、使命、物质环境、标准、传统、价值观、 办学实践、信仰、假说等诸多因素综合起来的且相互影响而 形成的指导高校个体或团体行为以及认识理解校园内外一些 
事件、行为提供参考框架的一种模式 ${ }^{[2]}$ 。国际上多数学者将 校园文化置于高职教育乃至整个教育领域的视域下进行研究, 强调校园文化建设对于高职院校办学水平提升的重要作用。

2010 年中国颁布的《国家中长期教育改革和发展规划纲 要》要求着力培养高职学生的职业道德、职业技能和就业创 业能力, 从而满足经济社会对高素质劳动者和技能型人才的 需要 ${ }^{[3]}$ 。拥有特色鲜明的校园软硬件文化, 能帮助高职院校 顺利完成为国家输送一线专业技术人才的目标; 能为企业降 低人力资源成本，提升工作效率，增加经济产出; 同时也有 利于社会和家庭的稳定与和谐。因此, 在高职院校校园文化 建设的优化上, 必须 “软硬兼施” , 从而使学生、学校、企业、 社会凹方收益。

\section{3 存在的主要问题}

\section{1 环境建设不够, 相关服务设施形同虚设}

美好的环境，不仅能起到润色校园的作用，更能在潜移 默化中熏陶校园的人文气息，提升校园文化。现如今，高校 的硬件设施建设可谓趋向一流。体育馆里，羽毛球场、游泳 池、篮球场、健身房应有尽有。图书馆，冬暖夏凉，电子阅 览室配置先进, 阅读环境舒适宜人。这些场所都是丰富学生 校园文化生活的理想之地。但现实状况却是, 图书馆门可罗雀, 唯有考试前夕一座难求。体育馆大门紧锁, 唯有体育课时稍 加利用。对于体院馆等设施, 一方面建设投入较大, 需要维护 ${ }^{[1]}$ 。 另一方面, 出于安全考虑, 学校不得已采取紧闭大门的措施 来避免学生意外事故的发生。对于图书馆, 由于高职学生的 学习主动性欠缺, 因此尽管馆藏丰富, 专业课本齐全, 硬件 条件优越, 仍然不能吸引学生们的眼球, 造成图书馆 “只备 一时之需” 的存在。“人” 是校园文化建设中的核心, 缺少 “人”, 再完善的硬件设施也只能沦于摆设。

\section{2 活动质量不高, 活动设计具有 “排他” 性}

学校的校园文化生活不可谓不丰富。每天都可以在学校 的公告栏上看到各种活动的宣传海报, 有电影节、有影视欣 赏节、有英语文化节……表面上这些形式各样的活动已经可 以满足大多数学生的课余时间活动需求, 但实际生活中, 参 与这些校园活动的主力军只是一小部分活跃同学, 或者资优 同学。例如英语拼写比赛, 报名参赛对象虽为全体学生, 但 真正进人比赛的却是极少数英语强人; 例如体能大比拼, 对
大多数身体素质平平的学生来说几乎连报名的勇气也没有。 有些活动由于没有人报名, 最后学生会干部为了向学校交差, 人为的拉拢一些熟识的学生来参加, 最后拍几张所谓的活动 照片草草了事。

当然, 不能否认这些活动的存在的确为丰富校园文化增 添了色彩, 但是就目前的活动参与度来说, 这样的色彩显然 还不够浓烈，不够吸引眼球，不能调动全员参与的积极性。 活动设计有待进一步完善。

\section{3 校企联动不足, 职业内涵体现欠缺}

高职院校的办学背景一般都有明显的行业特色, 高职院 校的培养目标通常也顺应行业要求, 以为企业提供 “能用好 用” 的一线人才为主。然而书本教学具有一定的滞后性, 其 更新迭代的速度不及行业发展。学生通过课堂可以掌握扎实 的理论基础, 但对当前最先进的行业技术掌握则相对薄弱。 这直接导致学生在实习初期的职业自信下降, 学习周期拉长, 企业的培训成本也相应增加。

笔者认为, 企业深入学校可以不必仅仅停留在每学年的 就业阶段。培养学生的职业素养, 使学生对行业有明确的认 知和了解, 需要从入校一始便让其耳濡目染, 对其加以熏陶, 将行业企业文化根植于心。而高职院校则可主动联系企业, 邀请企业管理人员参与校园文化建设, 本着互惠共赢的原则, 充分结合 “校企合作、工学交替” 的教育形式将企业文化深 入融合到校园文化的建设之中, 通过一系列文化活动的开展, 达到润物细无声的效果。

\section{4 优化建议}

\section{1 充分开放校内资源, 吸引学生眼球}

高职学生正处于心理和生理的活跃期, 研究显示, 适当 的体育活动不但能够强健体魄, 对于释放心理压力、调节情 绪亦有很大帮助。因此, 应当鼓励学生在课余时间积极投身 到体育运动当中, 通过运动来帮助塑造和完善健康人格。对此, 学校应当充分开放校内体育场馆, 不能因为害怕学生会损害 设施或者带来意外人身伤害纠纷而选择草率关闭场所, 此举 非但不能杜绝意外发生, 更有可能助长学生其他不良行为的 养成，造成更坏的后果。

对于校方介意的学生因为在校期间造成人身伤害而带来 的纠纷与赔偿问题, 其实可以有更好的应对方法, 例如由相 
\begin{tabular}{|l} 
综述性文章 \\
Review
\end{tabular}

关教育部门牵头设计相关险种, 投保人和收益人均为学校, 专门用于赔偿学生在校期间发生的主体责任不在校方的意外 伤害事故, 解决校方的后顾之忧, 让体育场所不再形同虚设, 使其成为学生课余时间活动的首选之处。

至于图书馆, 它肩负着校园文化建设的重任, 是学校教 育从课堂到课余的延伸。因此, 要深入高职学生的生活, 学 校图书馆必须改变 “以我为中心” 的老旧运作方式，不能坐 等学生来, 而要走到学生中去。主动联合专业教师、学生会 和其他相关部门, 组织开展一些以 “阅读” 为主题的系列活动。 例如, 举办知识竞赛。赛题可以出自图书馆指定书目, 也可 以由专业教师指导用书, 让书本活起来, 以实际行动鼓励学 生真正走进图书馆, 丰富学生的课余文化生活, 提高学生的 学习主动性。

\section{2 提高文化活动质量及参与度}

学校的课余活动一般由团委和学生会两个部门牵头组织。 通常由学生设计活动内容, 团委辅助协调活动场地及活动设 施。那么首先, 应当从活动的设计出发, 尽量降低活动的准 入门槛, 丰富活动的种类, 拓展活动的形式。例如, 针对高 职男生喜欢网络游戏的特点, 开展一场网络游戏的竞技比赛。 虽然这样的活动表面上助长了学生沉迷网络的不良风气。但 不妨换一个角度思考, 既然网络已经成为学生生活不可分割 的一部分, 教育方式如果还一味采取 “堵” 的策略必然不能 取得成效, 不如转变观念, 用正确引导、适当控制的新思路 取代严格杜绝、只堵不疏的老方法 ${ }^{[2]}$ 。一来, 好的网络游戏 可以适当提升个人的操作能力, 与高职学生的培养目标相符。 二来, 在比赛的过程中, 学校可以充分了解学生的思想动态, 贴近学生的课余生活, 将学生的行为正向化、有序化, 同时 培养学生的竞争意识, 为他们从学校走上社会打好基础。

当然，好的活动少不了专业的指导和监督，学校如果可以 调动相关部门积极 配合, 鼓励专业老师参与督导, 将活动内容 与课堂教学相结合, 帮助学生坚立良好的职业素养, 这样的活 动无论在参与度和质量控制上都会取得较为良好的效果。

\section{3 畅通校园文化与企业文化的融合渠道}

当前部分高职院校在建立校园文化的过程中将本科院校
的方式方法照搬照抄, 背离了办学初衷, 也偏离了办学目标。

“工学结合” 是当前职业教育的亮点, 高职院校可以将 “工 学结合” 的举措进一步灵活运用, 从课堂延伸至课后, 将企 业文化精神渗透到学校活动的各个环节。除了定期邀请企业 管理人员开展讲座, 还可以将企业管理的模式套用到学生管 理上, 比如将学生纪律考核按照企业标准操作、用绩效考核 模式取代加减分模式、用薪金制对学生的行为加以约束和激 励, 以企业架构来构建班集体等, 让学生在校期间时刻体会 到企业的氛围, 感受企业的文化, 从而养成良好的责任意识 和行为习惯，为成为合格的职业人打好坚实基础。

\section{5 结语}

从 2009 年起, 笔者便供职于上海民航学院, 见证了其从 一所中等专业学校成长为一所行业知名高职院校的过程。我 校是为民航事业输送人才的重要基地, 肩负着为民航培养一 线员工的重要责任, 要求学生具备坚定的政治立场、良好的 个人作风、严谨的处事态度以及㜀熟的操作技能。

期间, 随着学校办学规模的扩大、招生人数的上升, 教 育部门和隶属单位在资金上给予了学校建设大力支持, 使学 校面貌焕然一新, 校园硬件设施得到了很大程度上的完善, 体现了国家在政策上对高等职业教育的倾斜。校园环境的改 善是校园文化建设的基石，反映高职院校行业特色的同时， 也于无形中强调了学习至上的学生使命。然而仅有硬件文化 是不能帮助学校完成为国家输送一线专业技术人才的目标, 必须在软件文化建设上同时予以跟进，达到 “软硬兼施”。

没有文化的校园是空洞的校园。高职院校必须充分重视 校园文化的建设, 坚持职业教育道路不动摇, 从而开创出具 有高职院校特色的校园文化。

\section{参考文献}

[1] 杨泉良, 赵宗尹. 高职院校校园文化建设概论 [M]. 济南: 山东大 学出版社. 2005 .

[2] 罗时髦. 企业合作背景下的高职校园文化建设研究 [D]. 武汉: 华 中师范大学. 2012

[3] 国家中长期教育改革和发展规划纲要 (2010-2020 年) 